\title{
Integrating IT Audit Into The AIS Course
}

Martin J. Coe, (E-mail: mj-coe@wiu.edu), Western Illinois University

\begin{abstract}
Information Technology (IT) has caused the accounting profession to change at a rapid pace during the last forty years. Indeed, technology is so pervasive in the accounting profession that it would be difficult for many companies to meet their accounting and financial reporting objectives without using technology. As a result, IT audit and control concepts play a very important role in the current business environment. Accordingly, the need for accounting students to understand IT auditing concepts has evolved to a point that warrants required coverage of IT audit concepts in the accounting curriculum. This paper provides research results that identify where accounting curriculums currently cover IT auditing concepts, what IT auditing concepts should be included in the accounting curriculum and where IT auditing concepts should be covered in the accounting curriculum.
\end{abstract}

\section{INTRODUCTION}

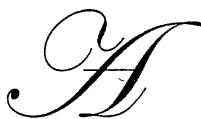

11 professions change over time. They adapt to changes in culture and politics, shifting economic conditions, scientific discoveries, technological innovations and a host of other developments that mark the evolution of societies. Over the past forty years numerous study groups have recommended changes in various aspects of accounting education. Recommendations for changes have been offered on a wide range of topics including: accreditation, governance structure, required hours beyond the baccalaureate degree, the appropriate content and format of licensure examinations, and the structure and content of the curriculum.

Information Technology (IT) has caused the accounting profession to change at a rapid pace during the last forty years. Indeed, technology is so pervasive in the accounting profession that it would be difficult for many companies to meet their accounting and financial reporting objectives without using technology. As a result, IT audit and control concepts play a very important role in the current business environment. Accordingly, the need for accounting students to understand IT auditing concepts has evolved to a point that warrants required coverage of IT audit concepts in the accounting curriculum.

\section{LITERATURE REVIEW}

\section{Need For IT Audit}

The explosive growth of IT capabilities and the desire of businesses of all sizes to obtain a competitive advantage have led to a dramatic increase in the use of IT systems to originate, process, store and communicate information. Today, employees at all levels use IT systems in their daily activities. Electronic records have replaced traditional paper documents. In fact, there are few companies that don't rely on IT to at least some extent to achieve their financial reporting, operating and compliance objectives. As a result, it is rare to find an entity whose IT use does not also affect its independent audit. ${ }^{1}$

The foundations of auditing are competence, independence, and due professional care. All three affect the quality and the value of an audit. In today's environment, where audit evidence is increasingly digital in nature, the exercise of competence and due professional care have taken on a new and different character. Competence relates to an auditor's technical ability to discover a material misstatement in the financial statements and is a function of education, training, and experience. It enables an auditor to collect evidence to support the audit opinion and weigh it in order to determine if the evidence is sufficient and reliable. Dramatic changes in information technology have changed the very nature of the evidence of transactions and have created a challenge for the audit profession to 
maintain its competence. The changes in the use of information technology by business have had a profound effect on accounting and auditing because these records are almost universally recorded, processed, and reported digitally. ${ }^{2}$

IT controls are part of the overall controls structure, working in combination with manual or user control procedures to manage business risk. The audit approach taken by a 21 st century internal audit department or external auditor needs to be driven by a shared assessment of the entity's business risks used by both financial and IT auditors. ${ }^{3}$

The U.S. General Accounting Office (GAO) and the National State Auditors Association (NSAA) published a guide to help state government agencies build the information security (IS) audit capabilities and skills many are lacking in the face of growing security threats. According to the document, Management Planning Guide for Information Systems Security Auditing, state agencies' increasing dependence on information technology and the Internet has exposed them to greater security risks. Yet, many agencies lack basic information-security plans, policies, controls, and skills. Understanding technology is the most glaring weakness of state government auditors, according to a skills-assessment survey of state government audit agencies conducted by GAO and NSAA in spring 2001. Survey results show that, overall, auditors had a minimal understanding of the technologies they audited. In 55 out of 75 technical categories, more than 40 percent of respondents wanted more training or experience in those areas of technology. ${ }^{4}$

Due to increased connectivity in the workplace, the average internal auditor receives considerably more exposure to IT systems than in the past. Technology plays a fundamental role in the way modern organizations function, and it has become integrated to the degree that virtually every type of audit requires at least some consideration of IT issues. Whereas technology was once considered the domain of specialized IT auditors, it is now the concern of all auditors, including audit generalists. ${ }^{5}$

E-Business introduces new challenges to conventional external auditors and the audit profession. Therefore, conventional manual audit techniques become inadequate for the electronic age. External auditors need to understand how the advanced technology affects their audit process. They also need to acquire the necessary knowledge and skills about this technology to be able to deal with the audit of electronic transactions on a daily basis using continuous audit approaches. ${ }^{6}$

The growth of enterprise-wide computing presents many new challenges for the audit of year-end financial statements. Paper trails and control checkpoints that were once standard for an audit firm are now available only in electronic form. If traditional methods of testing controls continue to be used, significant risks may go unnoticed. When dealing with advanced information systems, the auditor may not be able to reduce detection risk to an acceptable level by relying solely on substantive tests. Auditing standards require that if the client uses technology to process data the technological infrastructure must be audited. Testing of sophisticated controls including firewalls, encryption of sensitive information, passwords, and authentication of electronic images may be necessary when dealing with electronic evidence.

One area in which IT has had a major influence on companies and their auditors is in preparing financial statements. Few organizations today do not use IT at least to maintain the general ledger, and most entities have automated the process of entering transaction totals and adjustments (including journal entries) into the general ledger and preparing financial statements. Gone are the days when auditors could examine manually prepared cash-receipt journals and check registers, trace monthly totals to handwritten entries in the general ledger (noting erasures or changes) and examine manually prepared worksheets combining general ledger accounts for the first pencil draft of the financial statements. ${ }^{8}$

Information technology can represent a key factor in an auditor's assessment of financial reporting controls. Compliance with Sarbanes-Oxley requires that reporting rise from the transaction level all the way to its final destination in the financial statements. In the course of this journey, internal control processes across significant business units must be examined end-to-end, which in turn requires an integrated evaluation of automated, ITdependent, and manual controls in relation to each other. ${ }^{9}$ 
The Public Company Accounting Oversight Board (PCAOB) Auditing Standard No. 2 states: The nature and characteristics of a company's use of information technology in its information system affect the company's internal control over financial reporting. ${ }^{10}$ The PCAOB standard incorporates by references auditing standards which discuss the effect of information technology on internal control over financial reporting. ${ }^{11}$

Technology plays an important role in most businesses. Recent regulations have highlighted the importance of IT controls as well as the responsibility to audit such controls. Accordingly, accountants and auditors need to understand IT audit and control concepts.

\section{Coverage Of IT Audit Concepts In Auditing Courses}

The results of a survey of auditing and assurance courses in the U.S. and several other countries conducted during 2000-2001, commissioned by the Auditing Section of the American Accounting Association, yielded data on auditing and assurance courses taught at colleges and universities in the United States, Canada, and several other countries. The syllabi data were analyzed on a number of dimensions and the results compared to two prior surveys of auditing courses. The findings noted substantial changes in content (e.g., new or expanded coverage of fraud, information technology, and assurance services) and pedagogy (e.g., increased use of team projects, student presentations, cases, and the Internet) in both introductory and advanced auditing courses over the past several years. The analysis identified nine distinct auditing curriculum models among the institutions in the sample. These models range from a single financial auditing course at the undergraduate level to several specialized auditing courses at the graduate level. The final sample included 262 auditing course syllabi from 188 colleges and universities. These courses were analyzed for topical content and types of course materials used. This analysis indicated that 63.4 percent of the introductory auditing courses covered general IT audit concepts. ${ }^{12}$

\section{Coverage Of IT Audit Concepts In IT Auditing Courses}

The results of a survey of auditing and assurance courses in the U.S. and several other countries conducted during 2000-2001, commissioned by the Auditing Section of the American Accounting Association, included 11 syllabi for information systems (IS) auditing courses. IS auditing courses make up 12.9 percent of the advanced courses in the current sample. The nine most frequently covered topics from current IS audit courses (included in at least 2 of the 11 syllabi) are shown below. ${ }^{13}$

\begin{tabular}{|l|c|c|}
\hline Topic & Frequency $\mathbf{( n = 1 1 )}$ & Percent \\
\hline Internal Controls & 10 & 90.9 \\
\hline Assurance Services & 9 & 81.8 \\
\hline Computer-Assisted Audit Tools/Techniques & 9 & 81.8 \\
\hline Auditing e-Commerce & 6 & 54.6 \\
\hline Fraud & 4 & 36.4 \\
\hline Substantive Testing - Revenue Cycle & 4 & 36.4 \\
\hline Substantive Testing - Purchasing Cycle & 4 & 36.4 \\
\hline Continuous/Online Auditing & 3 & 27.3 \\
\hline Other & 2 & 18.2 \\
\hline
\end{tabular}

\section{Coverage Of IT Audit Concepts In AIS Courses}

AIS education has evolved. In the early 1980's, the AIS course was undefined. Consider the following AIS history ${ }^{14}$ : In 1984 Romney suggested that one reason the accounting systems course had been designated as a "problem" course by instructors is that, unlike principles of accounting or cost accounting, there was no general agreement on the content of the course. In 1984 Gelinas and Verrault claimed the accounting systems course was "non-standardized." In 1984 Hooks and Siebel agreed that the accounting systems course body of knowledge was not yet well-defined and varied from textbook to textbook and from instructor to instructor. According to Wu in 1983 and Cerullo in 1981, academics did not agree on what topics should be taught in the accounting systems course. In 1983 
Jensen and Arrington believed that too few curriculum changes had been made to accommodate the more modern information systems, internal control, and electronic data processing procedures that were becoming increasingly more common in practice.

AIS courses have certainly become better-defined since the early 1980's. Just as AIS concepts have evolved to become required components of the accounting curriculum, IT auditing concepts need to become a required part of the accounting curriculum.

\section{IT Audit Topics}

In 1975 Jancura was one of the first academics to develop a specific listing of required technical skills for IT auditors. Her proficiency requirements included such areas of knowledge as operating systems, audit software, and data structures. Later, this work was extended to include the concepts of general and application controls as delineated in Statement on Auditing Standards No. 3 and was further expanded into a matrix to indicate three levels of IT audit knowledge: general staff auditor, EDP specialist, and audit supervisor. ${ }^{15}$

\begin{tabular}{|l|c|}
\hline \multicolumn{1}{|l|}{ Summary of Topics by Model Area } & Hours \\
\hline 1. Audit Process & \\
\hline IS Audit Function Knowledge & 6 \\
\hline Fundamental Auditing Concepts & 7 \\
\hline Standards and Guidelines for IS Auditing & 5 \\
\hline Internal Controls Concepts Knowledge & 13 \\
\hline Audit Planning Process & 7 \\
\hline Audit Management & 5 \\
\hline Audit Evidence Process & 12 \\
\hline Audit Reporting Follow-up & 3 \\
\hline 2. Management, Planning and Organization of IS & \\
\hline IS/IT Management & 10 \\
\hline IS/IT Strategic Planning & 8 \\
\hline IS/IT Management Issues & 9 \\
\hline Support Tools and Frameworks & 6 \\
\hline Techniques & 4 \\
\hline 3. Technical Infrastructure and Operational Practices & \\
\hline Technical Infrastructure (Planning, Implementation and Operational Practices) & 25 \\
\hline Service Center Management: Maintenance of Information Systems and Technical \\
Infrastructures Through Organizations Dedicated to These Activities & 12 \\
\hline 4. Protection of Information Assets & \\
\hline Information Assets Security Management & 8 \\
\hline Logical IT Security & 9 \\
\hline Applied IT Security: High-technology Resources & 9 \\
\hline Physical and Environmental Security & 3 \\
\hline 5. Disaster Recovery and Business Continuity & \\
\hline 6. Business Application System Development, Acquisition, Implementation and Maintenance \\
\hline 7. Business Process Evaluation and Risk Management \\
\hline
\end{tabular}

As the IT audit profession evolved, the Information Systems Audit and Control Association (ISACA) surfaced as the dominant IT audit and control organization. ISACA also plays a role in IT audit education. ISACA's Model Curriculum 2004 and relevant details were released in the third quarter 2004. The model is organized around the content areas that currently compose the CISA examination. Discussions with academics and professionals from around the globe indicated that a comprehensive curriculum to train entry-level IS audit and control professionals would often include in excess of 300 contact hours. Developing the proper amount of time to be devoted to any topic or subtopic is subject to many differing opinions, but some estimate of an average amount of time was necessary. As a result the contact hours in the model total 244 hours, which is approximately 80 percent of the 300 hours that were 
previously discussed. ${ }^{16}$ The following table depicts the hour estimates that have been assigned to each of the topic areas within the seven domains.

Educational organizations can structure their delivery system components (e.g., courses, modules) to include topics from anywhere within the model, and they are not limited to any predetermined component structures. To determine compliance with the model, the educational institution can create a mapping of where the model curriculum topics were delivered within its educational delivery system components. This mapping can be as simple as providing detailed syllabi of courses taught at a university and matching where items from the model curriculum are covered in the courses. Organizations that implement the new model curriculum will receive benefits that have not previously been available. After an institution's mapping of its curriculum has been submitted to ISACA and the institution's programs are found to be in compliance with the model, the institution will be recognized on the ISACA web site as having adopted the ISACA model. In addition, students that graduate from an approved, compliant program will automatically qualify for one year of work experience toward the Certified Information Systems Auditor (CISA) certification. ${ }^{17}$

Utilizing ISACA's Model Curriculum may not be possible for some colleges and universities. Indeed, the accounting curriculum should not be expected to cover all the IT audit topics mentioned in ISACA's Model Curriculum, however the topics should be considered when deciding which IT audit concepts to cover in the accounting curriculum.

\section{Contribution of This Study}

Given the need for accountants and auditors to understand IT audit and control concepts, it appears that the accounting curriculum should require students to master IT audit and control concepts. A review of the literature indicates that the following questions need to be answered:

1. Where do accounting curriculums currently cover information technology auditing concepts?

2. What information technology auditing concepts (learning outcomes) should be included in the accounting curriculum?

3. Where should information technology auditing concepts be covered in the accounting curriculum?

This study provides research results that identify where accounting curriculums currently cover IT auditing concepts, what IT auditing concepts should be considered in the accounting curriculum and where IT auditing concepts should be covered in the accounting curriculum.

\section{RESEARCH METHODS}

The following research was performed:

- $\quad$ Colleges and universities were surveyed.

- $\quad$ Accounting curriculums were reviewed via the Internet.

- Textbooks were analyzed.

\section{Survey Method}

Using Hasselback's 2004-2005 Accounting Faculty Directory ${ }^{18}$, a database of schools was created. Surveys with a personalized cover letter were sent to individuals identified as chairs in the database. The chairs were asked to answer the questions or forward the survey to the person at their school who is best qualified to respond. This approach assumed that the chairs would either know how to answer the questions or would know who to forward the survey to at their school. The survey questions were introduced with the following text:

I am conducting research to identify the extent to which accounting curriculums are covering information technology auditing concepts. I kindly request that you answer the survey questions on the back of this page or forward the 
survey to the person at your school who is best qualified to respond. This survey should take only a few minutes to complete and can be returned in the stamped envelope provided. Thank you very much for your help.

The survey contained the following questions:

1. How many accounting hours are required in your:

Business Core

\section{Accounting Major}

2. Where does your accounting curriculum cover information technology auditing concepts? (Check all that apply.)

$\square$ Auditing Course

$\square$ Accounting Information Systems Course

$\square$ Information Technology Auditing Course

$\square$ Other Course (please identify)

3. If you have an information technology auditing course, is it required?

$\square$ Yes

$\square$ No

$\square$ Not Applicable

The primary objective of the survey was to identify where IT audit concepts are covered in the accounting curriculum (questions two and three). Since one issue that must be considered when deciding to add a new learning outcome to a course is time, a secondary objective was to identify how many accounting hours are required in the business core and accounting major (question one).

\section{Internet Research Method}

This research was performed using the database created from Hasselback's 2004-2005 Accounting Faculty Directory $^{19}$. Each school's Internet site was accessed. Information was sought regarding the accounting department, business school, or accounting major. Course descriptions and other information on the Internet site were analyzed to determine if the school appeared to offer an IT audit course. Based on this analysis, the schools were categorized as follows:

1. Offers IT Auditing Course

2. Does not offer IT Auditing Course

3. Webpage does not provide descriptive enough course information to reasonably conclude whether or not the school offers an IT Auditing Course. (This could mean that course descriptions were not available or that the webpage itself was not functioning during the research period.)

\section{Textbook Analysis Method}

The textbooks offered by publishers were reviewed to identify auditing, IS auditing and AIS textbooks. From this review:

1. Eight auditing textbooks were analyzed to determine if they cover IT control and IT audit concepts.

2. Four IS auditing textbooks were analyzed to determine if they cover IT control and IT audit concepts.

3. Ten AIS textbooks were analyzed to determine if they cover IT control and IT audit concepts.

\section{RESULTS}

\section{Survey Results}

Responses were received from 330 of 800 surveys mailed and received. (809 surveys were mailed and 9 were returned.) Thus, the response rate was $41.25 \%$ (330/800). The survey results follow. 
Question 1A: How many accounting hours are required in your business core?

Responses: 323

Average Response: 9.57

Modal response: 6

If a range of hours was provided, the upper limit was used.

In reviewing the responses, it appeared that some respondents provided the total number of hours required in their business core rather than the accounting hours. Thus, the modal response is most likely the best indication of the accounting hours required in the business core. This concern was further addressed by removing the responses greater than 21 and re-tabulating the results. The results were:

Responses <21: 290

Average $<21: 6.37$

Modal response $<21: 6$

Question IA Conclusion: It appears that most of the schools surveyed require 6 accounting hours in their business core.

Question 1B: How many accounting hours are required in your accounting major?

Responses: 316

Average Response: 28.03

Modal Response: 24

Question IB Conclusion: It appears that most of the schools surveyed require 24 accounting hours in their accounting major.

Question 2: $\quad$ Where does your accounting curriculum cover information technology auditing concepts?

Responses: 321

The courses identified are depicted in the following table. (The survey instrument allowed respondents to indicate more than one course.)

\begin{tabular}{|l|c|c|}
\hline Course & Responses & Percentage \\
\hline Auditing Course & 242 & 75.39 \\
\hline Accounting Information Systems Course & 218 & 67.91 \\
\hline Information Technology Auditing Course & 27 & 8.41 \\
\hline Other Course & 40 & 12.46 \\
\hline
\end{tabular}

Other Courses Listed (\# Of Responses):

Business Information Technology/Information Systems (7)

Management Information Systems (6)

Advanced Auditing (5)

Auditing Seminar (3)

Auditing II (2)

Business Processes and Accounting Controls (1)

Graduate course in IS auditing (1)

Junior level combined course (1)

IT 403: Computer Control and Audit (1)

Internal Auditing (1)

Micro. Computer Applications - soph. level (1)

Cost, Auditing, Advanced, and Tax (1)

Extra volunteer session for those taking CPA exam (1)

Accounting Technology (1)

2 audit courses (1) 


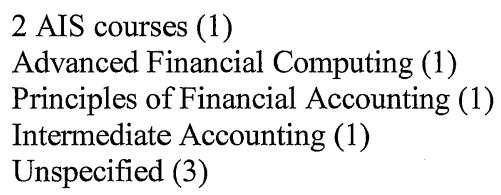

Question 2 Conclusion: It appears that most of the schools surveyed cover IT auditing concepts in their auditing or AIS courses.

Question 3: $\quad$ If you have an information technology auditing course, is it required?

Responses: 316

Yes: $35-11.08 \%$

No: $65-20.57 \%$

N/A: $216-68.35 \%$

Some respondents appeared to be indicating whether the course they referred to in question 2 was required, regardless of whether that course was an IT Auditing Course. Since question 3 was intended to gather data concerning whether an IT Auditing Course specifically was required, the responses to question 3 were filtered, and the responses to question 3 were re-tabulated only for those surveys which indicated in question 2 that information technology auditing concepts were covered in an IT auditing course. The results were:

Responses: 24

Yes: $9-37.5 \%$

No: $15-62.5 \%$

Question 3 Conclusion: It appears that most of the schools that use an IT audit course to cover information technology auditing concepts do not require the course to be taken.

Comments: $\quad$ Some surveys contained comments. The most common comments were:

1. Our school does not have an undergraduate accounting program.

2. The IT Auditing Course is required in a graduate but not an undergraduate program.

3. IT auditing is covered only minimally in our program.

4. Responses are for undergraduate program.

5. IT Audit Course is an elective.

6. Requirements will be changing in coming years.

\section{Internet Research Results}

Total Schools Researched: 809

Schools With Information Unavailable: 93

Schools With Information Available: 716

Of the 716 schools with information available, the results were:

\begin{tabular}{|l|c|c|}
\hline & Schools & Percent \\
\hline Schools Which Offer an IT Auditing Course & 63 & 8.8 \\
\hline Schools Which Do Not Offer an IT Auditing Course & 653 & 91.2 \\
\hline
\end{tabular}

\section{Textbook Analysis Results}

Textbooks were reviewed in an attempt to identify the extent to which IT audit concepts are covered in auditing, IT auditing and AIS courses. Of course, textbook coverage is not always representative of content covered in a given course, but it provides a gauge. 


\begin{tabular}{|c|c|c|}
\hline Auditing Textbooks & $\begin{array}{l}\text { IT Control } \\
\text { Coverage }\end{array}$ & IT Audit Coverage \\
\hline $\begin{array}{l}\text { Arens Alvin A., Beasley, Mark S., and Elder, Randal J. Auditing and } \\
\text { Assurance Services 10th ed. Prentice Hall, 2005. }\end{array}$ & No & Impact Discussed \\
\hline $\begin{array}{l}\text { Konrath, Larry F. Auditing: A Risk Analysis Approach 5th ed. Thomas } \\
\text { South-Western, } 2002 .\end{array}$ & Impact Discussed & No \\
\hline $\begin{array}{l}\text { Louwers, Timothy J., Ramsay, Robert J., Sinason, David, and Strawser, } \\
\text { Jerry R. MP Auditing and Assurance Services 1st ed. McGraw-Hill, } \\
2005 .\end{array}$ & No & No \\
\hline $\begin{array}{l}\text { Messier, William F. Auditing \& Assurance Services 3rd ed. McGraw- } \\
\text { Hill, 2003. }\end{array}$ & No & Impact Discussed \\
\hline $\begin{array}{l}\text { Messier, William F, Glover, Steven M., and Prawitt, Douglas F. } \\
\text { Auditing \& Assurance Services: A Systematic Approach 4th ed. } \\
\text { McGraw-Hill, 2006. }\end{array}$ & No & No \\
\hline Ricchiute, David. Auditing 8th ed. Thomas South-Western, 2006. & No & No \\
\hline $\begin{array}{l}\text { Rittenberg, Larry E. and, Schwieger, Bradley J. Auditing: Concepts for } \\
\text { a Changing Environment 5th ed. Thomas South-Western, } 2005 .\end{array}$ & Impact Discussed & No \\
\hline $\begin{array}{l}\text { Whittington, Ray and Pany, Kurt. MP Principles of Auditing 14th ed. } \\
\text { McGraw-Hill, } 2004 .\end{array}$ & Impact Discussed & No \\
\hline
\end{tabular}

Four IS auditing textbooks were analyzed to determine if they cover IT control and IT audit concepts. The results are depicted below:

\begin{tabular}{|l|c|c|}
\hline IT Auditing Textbooks & $\begin{array}{c}\text { IT Control } \\
\text { Coverage }\end{array}$ & IT Audit Coverage \\
\hline Champlain, Jack J. Auditing Information Systems, 2nd ed. Wiley, 2003. & Yes & Yes \\
\hline $\begin{array}{l}\text { Hall, James A. and Singleton, Tommie. Information Technology Auditing } \\
\text { and Assurance 2nd ed. Thomson Southwestern, 2005. }\end{array}$ & Yes & Yes \\
\hline $\begin{array}{l}\text { Hunton, James E., Bryant, Stephanie M., and Bagranoff, Nancy A. Core } \\
\text { Concepts of Information Technology Auditing. Wiley, 2003. }\end{array}$ & Yes & Yes \\
\hline $\begin{array}{l}\text { Weber, Ron A. Information Systems Control and Audit. Prentice Hall, } \\
1999 .\end{array}$ & Yes & Yes \\
\hline
\end{tabular}

The four IS auditing textbooks were further analyzed to identify the topics covered. The results are depicted below:

\begin{tabular}{|c|c|c|}
\hline Topic & Frequency $(n=4)$ & Percent \\
\hline IT Audit Concepts & 4 & $100 \%$ \\
\hline IT Control/Security & 4 & $100 \%$ \\
\hline IT Concepts & 3 & $75 \%$ \\
\hline Computer Assisted Audit Tools/Techniques & 3 & $75 \%$ \\
\hline Fraud/Forensics & 3 & $75 \%$ \\
\hline Assurance Services & 2 & $50 \%$ \\
\hline Testing & 2 & $50 \%$ \\
\hline Other & 2 & $50 \%$ \\
\hline
\end{tabular}


Ten AIS textbooks were analyzed to determine if IT control and IT audit concepts are covered. The results are depicted below:

\begin{tabular}{|l|c|c|}
\hline AIS Textbooks & $\begin{array}{c}\text { IT } \\
\text { Control } \\
\text { Coverage }\end{array}$ & $\begin{array}{c}\text { IT } \\
\text { Audit } \\
\text { Coverage }\end{array}$ \\
\hline $\begin{array}{l}\text { Bagranoff, Nancy A., Simkin, Mark G., and Norman, Carolyn Strand. Core Concepts of } \\
\text { Accounting Information Systems 9th ed. Wiley, 2004. }\end{array}$ & Yes & Yes \\
\hline $\begin{array}{l}\text { Bodnar, George H. and Hopwood, William S. Accounting Information Systems 9th ed. } \\
\text { Prentice Hall, 2004. }\end{array}$ & Yes & Yes \\
\hline $\begin{array}{l}\text { Dunn, Cheryl, Cherrington, J. Owen, and Hollander, Anita Sawyer. Enterprise Information } \\
\text { Systems: A Pattern-Based Approach 3rd ed. McGraw-Hill, 2005. }\end{array}$ & Yes & No \\
\hline $\begin{array}{l}\text { Gelinas, Ulric J. and Sutton, Steve G. Accounting Information Systems 6th ed. Thomson } \\
\text { Southwestern, 2005. }\end{array}$ & Yes & No \\
\hline $\begin{array}{l}\text { Greenstein, Marilyn and Vasarhelyi, Miklos. Electronic Commerce: Security, Risk } \\
\text { Management, and Control 2nd ed. McGraw-Hill, 2002. }\end{array}$ & Yes & No \\
\hline Hall, James A. Accounting Information Systems 4th ed. Thomson Southwestern, 2004. & Yes & Yes \\
\hline $\begin{array}{l}\text { Jones, Frederick and Rama, Dasaratha. Accounting Information Systems A Business Process } \\
\text { Approach 2nd ed. Thomson Southwestern, 2006. }\end{array}$ & Yes & No \\
\hline $\begin{array}{l}\text { Romney, Marshall B. and Steinbart, Paul J. Accounting Information Systems 10th ed. Prentice } \\
\text { Hall, 2006. }\end{array}$ & Yes & Yes \\
\hline Vaassen, E. H. J. Accounting Information Systems: A Managerial Approach. Wiley, 2002. & Yes & No \\
\hline $\begin{array}{l}\text { Wilkinson, Joseph W., Cerullo, Michael J., Raval, Vasant, and Wong-On-Wing, Bernard. } \\
\text { Accounting Information Systems: Essential Concepts and Applications 4th ed. Wiley, 1999. }\end{array}$ & Yes & Yes \\
\hline
\end{tabular}

The ten AIS textbooks reviewed were further analyzed to identify the topics covered. The results are depicted below:

\begin{tabular}{|l|c|c|}
\hline Topic & Frequency $(\mathbf{n}=\mathbf{1 0})$ & Percent \\
\hline IT Control/Security & 10 & $100 \%$ \\
\hline Introduction to AIS & 9 & $90 \%$ \\
\hline Business Cycles/Transaction Processing & 8 & $80 \%$ \\
\hline Databases & 6 & $60 \%$ \\
\hline E-commerce & 6 & $60 \%$ \\
\hline SDLC or System Development & 6 & $60 \%$ \\
\hline Data Modeling/REA & 5 & $50 \%$ \\
\hline Documentation & 5 & $50 \%$ \\
\hline IT Audit & 5 & $50 \%$ \\
\hline Fraud/Crime/Ethics & 3 & $30 \%$ \\
\hline Other Topics & 6 & $60 \%$ \\
\hline
\end{tabular}

\section{CONCLUSIONS}

Information Technology has caused the accounting profession to change at a rapid pace during the last forty years. Indeed, technology is so pervasive in the accounting profession that it would be difficult for many companies to meet their accounting and financial reporting objectives without using technology. As a result, IT audit and control concepts play a very important role in the current business environment. Accordingly, the need for accounting students to understand IT auditing concepts has evolved to a point that warrants required coverage of IT audit 
concepts in the accounting curriculum. At this time, the AIS course is the most plausible place to cover IT audit concepts in the accounting curriculum.

\section{Rationale For Integrating IT Auditing Into AIS Course}

The majority of schools surveyed appear to cover IT auditing concepts in their auditing course (75.39\%). However, there are two problems with this approach. First, auditing textbooks do not provide extensive coverage of IT control and auditing concepts. Of course, the auditing course can be supplemented to expand IT audit and control concepts that are not in the textbook, but this would require significant efforts to achieve learning outcomes related to IT audit and control. The second problem is that individuals that are qualified to teach auditing may not be qualified to teach IT auditing.

While a separate IT audit course would be a great way to provide IT audit and control coverage, only a few of the schools surveyed appear to use an IT auditing course to cover IT auditing concepts (8.41\%). There are also two problems with this approach. First, in many cases the IT audit course is part of the graduate or fifth-year program. Thus, students may not receive exposure to IT auditing concepts in their undergraduate accounting experience. Second, of those schools that offer an IT audit course, only 37.5\% appear to require it. Thus, some students may never receive exposure to IT audit concepts as a part of their undergraduate or graduate accounting experience.

A high percentage of schools surveyed, appear to cover IT auditing concepts in their AIS course (67.91\%). There are two problems with this approach. First, not all AIS textbooks provide coverage of IT auditing concepts. However, the coverage is better than auditing textbooks. In addition, the AIS course can be supplemented to expand IT audit concepts that are not in the AIS textbook. Just like auditing, the second problem is that individuals that are qualified to teach AIS may not be qualified to teach IT auditing.

One issue that must be considered when deciding to add a new learning outcome to a course is time. Of the schools surveyed, most appear to require about 24 accounting hours in their accounting major. Thus, finding hours for new initiatives in the accounting curriculum is probably going to be a challenge for many schools. Given that IT audit concepts will have to be covered in the AIS or the auditing course, some AIS courses may more easily be able to add or modify learning outcomes compared to the auditing course. A phenomenon, now becoming a matter of history, is the increasing level of computing competence in accounting students, consistent with the general level of computer assimilation in society. As a result of this increased level of computing competency or coverage of IT concepts in other courses, some schools may be able to delete introductory information systems concepts that are currently covered in the AIS course and replace them with IT auditing concepts.

Of the three course alternatives (Auditing, IT Auditing and AIS), the AIS course appears to be best suited to cover IT audit and control concepts at this point in time. IT audit is currently part of most AIS courses and is a natural extension of the IT control discussion that is in most AIS courses. Indeed, the AIS course appears to offer the best opportunity to study IT auditing in the context of the IT controls that are critical in the Sarbanes Oxley world accounting graduates will be entering.

Every school must consider its own circumstances in deciding where to cover IT auditing concepts. It is less important where IT audit concepts are covered and more important that they are covered. In the short run, ensuring IT audit coverage with only minor curriculum change is probably wise. Major curriculum change does not occur easily. Challenges may be anticipated in several areas including resource constraints, reward systems, faculty and student reactions to change. ${ }^{20}$ Thus, since many schools would only need to make minor curriculum changes if they use their AIS course to ensure adequate coverage of IT auditing concepts, the AIS course might be the best alternative in the short run. 


\section{Approaches To Integrating IT Audit Into The AIS Course}

Assuming the AIS course is the place to cover IT auditing concepts, the following learning outcomes should be part of the AIS course:

1. Gain an understanding of IT controls that support business processes.

2. Gain an understanding of how to assess IT risk.

3. Gain an understanding of the IT audit process.

4. Gain an understanding of IT audit procedures related to general and application controls.

The question then becomes: how should these learning outcomes be achieved in an AIS course? Three approaches are discussed.

\section{Approach One: Use AIS Text}

Since there are several AIS textbooks available that cover both IT control and IT auditing concepts, one approach is to use an AIS textbook to achieve IT audit learning outcomes. Of course, the text must include both IT control and IT auditing concepts. This approach would be the easiest approach for many schools to implement. The problem with this approach is that it may lack the depth necessary to gain an understanding of IT audit procedures related to general and application controls. This is because the IT audit coverage in many of the AIS textbooks is limited to one chapter and does not always include a detailed discussion of IT audit procedures.

\section{Approach Two: Use AIS Text And Integrated IT Auditing Case}

The second approach addresses the depth problem in the first approach. This approach would also use an AIS textbook that includes IT control and IT auditing concepts to achieve IT audit learning outcomes. In addition, this approach would utilize an integrated IT auditing case to help students gain an understanding of IT audit procedures related to general and application controls. The integrated case could be used throughout the semester. The problem with this approach is that AIS textbooks do not include an integrated IT audit case. Thus, a case would have to be developed or obtained from a different source.

\section{Approach Three: Use AIS Text, Auditing Text And Integrated IT Auditing Case}

The third approach addresses the possibility that the AIS text may not include IT audit concepts. Many of the AIS textbooks that do not cover IT auditing are excellent texts. Accordingly, it may be desirable to adopt an AIS text that does not cover IT auditing and utilize an IT auditing textbook as a supplemental course material. Again, an integrated IT auditing case could be used to help students gain an understanding of IT audit procedures related to general and application controls. In addition to the need to develop or secure an integrated case, the problem with this approach is that it would require students to purchase two textbooks. An alternative to using the supplemental IT auditing text would be to just use the integrated IT auditing case with the AIS text even if the AIS text does not cover IT auditing.

\section{FUTURE RESEARCH}

IT audit concepts cannot be mastered from a book. The opportunity to experience IT auditing is crucial to the mastery of IT audit concepts. Since it is not always possible for students to perform real IT audits as part of the learning process, case studies can provide a method to gain IT audit experience. This paper demonstrates the need to develop integrated IT auditing cases. The cases should allow students to simulate an IT audit. This simulation could be accomplished with hypothetical background information that students would use to develop an IT audit program and perform procedures. Ideally, the cases would include electronic background data so that certain audit procedures could utilize the electronic data. The audit cases should allow students to actually experience or simulate audit 
procedures to meet audit objectives. The development of such cases will require research to accomplish the learning outcomes. Suggested learning outcomes include:

1. Gain an understanding of IT controls that support business processes.

2. Gain an understanding of how to assess IT risk.

3. Gain an understanding of the IT audit process.

4. Gain an understanding of IT audit procedures related to general and application controls.

The IT control documentation and test plans that some companies are required to develop to be in compliance with the Sarbanes-Oxley Act might be an excellent research source. Thus, cases could be developed in partnership with practitioners (with company-specific information removed or modified).

\section{REFERENCES}

1. Abu-Musa, Ahmad, Auditing E-Business: New Challenges for External Auditors, Journal of American Academy of Business, Cambridge, Vol. 4, No. 1/2, pp. 28-41, 2004.

2. AICPA Professional Standards, New York: American Institute of Certified Public Accountants, Section AU 319.

3. AICPA Top 10 Technologies, American Institute of Certified Public Accountants, $<$ http://www.aicpa.org/infotech/technologies/toptechs.htm>, 19 March 2005.

4. Armitage, H.M. and J.E. Boritz, Integrating Computers into the Accounting Curriculum, Issues in Accounting Education, Vol. 1, Issue 1, p. 86, 1986.

5. Arya, Anil, John C. Fellingham, and Douglas A. Schroeder, An Academic Curriculum Proposal, Issues in Accounting Education, Vol. 18, No. 1, pp. 29-35, 2003.

6. Bagranoff, Nancy A. and Valaria P. Vendrzyk, The Changing Role of IS Audit Among the Big Five USBased Accounting Firms, Information Systems Control Journal, Vol. 5, 2000.

7. Baldwin, Bruce A. and Dan C. Neer, EDP Audit Education and EDP Auditor Characteristics: Empirical Data from Practitioners and Professors, Issues in Accounting Education, Vol. 1, Issue 1, p. 153, 1986.

8. Bierstaker, James L., Priscilla Burnaby, and Jay Thibodeau, The Impact of Information Technology on the Audit Process: An Assessment of the State of the Art and Implications for the Future, Managerial Auditing Journal, Vol. 16, No. 3, pp. 159-164, 2001.

9. Brown, Jr., James F. and Thomas E. Balke, Accounting Curriculum Comparison by Degree Program of Schools Intending to Seek AACSB Accreditation, Issues in Accounting Education, Issue 1, p. 50, 1983.

10. Bedford, Norton, E.E. Bartholomew, Charles A. Bowsher, Abbott L. Brown, Sidney Davidson, Charles T. Horngren, Herbert C. Knortz, Mendel M. Piser, William G. Shenkir, John K. Simmons, Edward L. Summers, and John T. Wheeler, Special Report: Future Accounting Education: Preparing for the Expanding Profession, Issues in Accounting Education, Vol. 1, Issue 1, p. 168, 1986.

11. Champlain, Jack, Practical IT Auditing, Warren, Forham \& Lamont of RIA, New York, 2003.

12. Chan, Sally, Sarbanes-Oxley: The IT Dimension, Internal Auditor, Vol. 61, No. 1, pp. 31-33, 2004.

13. Codere, David G., Automating the Audit Function, Internal Auditor, Vol. 50, No. 5, pp. 18-20, 1993.

14. Dallas, Dennis A., The Role of IS Auditing in Today's Business Environment, Information Strategy Vol. 15, No. 3, pp. 45-48, 1999.

15. Davis, Charles E., The Field of Accounting...Bridging the Distance Between the Classroom and Practice, Baylor Business Review, Vol. 19, No. 2, pp. 12-13, 2002.

16. Diamond, R. M., Designing and Improving Courses and Curricula in Higher Education: A Systematic Approach (San Francisco: Jossey-Bass Inc., 1989).

17. Elliott, Robert K., The Future of Audits, Journal of Accountancy, Vol. 178, No. 3, pp. 74-82, 1994.

18. Elliott, Robert K. and Peter D. Jacobson, Adding Value to Audits, CA Magazine, Vol. 130, No. 9, pp. 35-37, 1997.

19. Fetters, Michael and John McKenzie, Does the Computer Hinder Accounting Education? An Analysis of Some Empirical Data, Issues in Accounting Education, Vol. 1, Issue 1, p. 76, 1986.

20. Frecka, Thomas J. and William D. Nichols, Characteristics of Master's in Accounting Degree Programs, Issues in Accounting Education, Vol. 19, No. 2, pp. 165-188, 2004. 
21. Gallegos, Frederick, Educating the Masses: Audit, Control, and Security of Information Systems Today and Tomorrow, Information Systems Control Journal, Vol. 6, 2004.

22. Gallegos, Frederick, IT Governance: IT Audit Role, Information Systems Control Journal, Vol. 4, 2003.

23. Hasselback, James R., Accounting Faculty Directory 2004-2005, Prentice Hall, Upper Saddle River, NJ, 2004.

24. Heagy, Cynthia D. and Peter L. McMickle, An Empirical Investigation of the Accounting Systems Course: Academic Practice Versus Practitioner Needs, Issues in Accounting Education, Vol. 3, Issue 1, p. 96, 1988.

25. Helmi, Medhat A., Integrating the Microcomputer Into Accounting Education - Approaches and Pitfalls, Issues in Accounting Education, Vol. 1, Issue 1, p. 102, 1986.

26. Helms, Glenn L. and Jane Mancino, The Electronic Auditor, Journal of Accountancy, Vol. 185, No. 4, pp. 45-48, 1998.

27. Hoffman, Thomas, IT Auditors Coveted, Hard to Find, Computerworld, Vol. 38, No. 18, pp. 1-16, 2004.

28. Information Systems Audit and Control Association, ISACA Model Curriculum for IS Audit and Control, $<$ http://www.isaca.org $>$, 19 March 2005.

29. Johnson, Eric N., Jane Baird, Paul Caster, William N. Dilla, Christine E. Earley, and Timothy J. Louwers, Challenges to Audit Education for the 21st Century: A Survey of Curricula, Course Content, and Delivery Methods, Issues in Accounting Education, Vol. 18, No. 3, pp. 241-263, 2003.

30. Kanter, Howard A., Systems Auditing in a Paperless Environment, Ohio CPA Journal, Vol. 60, No. 1, pp. 43-47, 2001.

31. Lord, Alan T. and Frederick Gallegos, ISACA Model Curriculum 2004: Continuing to Invest in the Future, Information Systems and Control Journal, Vol. 6, 2004.

32. Marks, Norman, The More Things Change..., Internal Auditor, Vol. 61, No. 4, pp. 60-64, 2004.

33. Mastracchio, Nicholas J., Jr., Auditing in the Classroom is Changing, Journal of Accountancy, Vol. 197, No. 4, pp. 11-13, 2004.

34. McCollum, T., IS Guidance for Government Auditors, Internal Auditor, Vol. 59, No. 2, pp. 16-17, 2002.

35. Mock, Theodore J., and Karen V. Pincus, A Systems Approach to Accounting Curriculum Development, Issues in Accounting Education, Vol. 6, Issue 2, p. 178, 1991.

36. Mueller, Gerhard G. and John K. Simmons, Change in Accounting Education, Issues in Accounting Education, Vol. 4, Issue 2, p. 247, 1989.

37. Myers, Gerald M. and Richard Vangermeersch, Book Reviews, Issues in Accounting Education, Vol. 5, No. $1,1990$.

38. Nearon, Bruce H., Foundations in Auditing and Digital Evidence, CPA Journal Vol. 75, No. 1, pp. 32-34, 2005.

39. Nelson, Irvin T., Valaria P. Bendrzyk, Jeffrey J. Quirin, and Robert D. Allen, No, the Sky Is Not Falling: Evidence of Accounting Student Characteristics at FSA Schools, 1995-2000, Issues in Accounting Education, Vol. 17, No. 3, pp. 269-287, 2002.

40. Pickard, Geoff, In the Public Interest, Journal of Accountancy, Vol. 199, No. 1, pp. 63-66, 69-70, 2005.

41. Pickard, Geoff, In the Public Interest, Part Two, Journal of Accountancy, Vol. 199, No. 2, pp. 60-62, 2005.

42. Public Company Accounting Oversight Board Bylaws and Rules - Standards: Auditing Standard No. 2. [Effective pursuant to SEC Release No. 34-49884; File No. PCAOB-2004-02, June 17, 2004].

43. Russell, Keith A. and Carl S. Smith, Accounting Education's Role in Corporate Malfeasance: It's Time for a New Curriculum! Strategic Finance, Vol. 85, No. 6, pp. 46-51, 2003.

44. Sayana, S. Anantha, The IS Audit Process, Information Systems Control Journal, Vol. 1, 2002.

45. Silltow, John, Shedding Light on Information Technology Risks, Internal Auditor, Vol. 60, No. 6, pp. 32-39, 2003.

46. Searcy, DeWayne L. and Jon B. Woodroof, Continuous Auditing: Leveraging Technology, CPA Journal, Vol. 73, No. 5, pp. 46-48, 2003.

47. Swauger, J., IIA Proposes New Audit Rules, Internal Auditor, Vol. 60, No. 1, p. 19, 2003.

48. Taylor, Virginia Anne and Martin Rudnick, Accounting Education: Designing a Curriculum for the $21^{\text {st }}$ Century, Journal of American Academy of Business, Cambridge, Vol. 6, No. 2, pp. 321-323, 2005.

49. Thomas, Paula B., The Competency-Based Preprofessional Curriculum: A Key Component of Vision Success, Journal of Accountancy, Vol. 190, No. 4, pp. 128-131, 2000.

50. Tucker, George H., IT and the Audit, Journal of Accountancy, Vol. 192, No. 3, pp. 41-43, 2001. 
51. Vorthick, A. Faye and Ronald L. Clark, Research on Computing in Accounting Education: Opportunities and Impediments, Issues in Accounting Education, Vol. 2, Issue 2, p. 173, 1987.

52. Wallace, Eric P., The Influence of Technology on Auditing, Pennsylvania CPA Journal, Vol. 72, No. 4, pp. 36-39, 2002.

53. Weidenmier, Marcia L. and Terri L. Herron, Selecting an Audit Software Package for Classroom Use, Journal of Information Systems, Vol. 18, No. 1, pp. 95-110, 2004.

54. Zhao, Ning, David C.Yen, and I-Chiu Chang, Auditing in the E-Commerce Era, Information Management \& Computer Security, Vol. 12, No. 5, pp. 389-400, 2004.

${ }^{1}$ George H. Tucker, "IT and the Audit," Journal of Accountancy, Vol. 192, No. 3, pp. 41-43, 2001.

${ }^{2}$ Bruce H. Nearon, "Foundations in Auditing and Digital Evidence," CPA Journal Vol. 75, No. 1, pp. 32-34, 2005.

${ }^{3}$ Norman Marks, "The More Things Change...," Internal Auditor, Vol. 61, No. 4, pp. 60-64, 2004.

${ }^{4}$ T. McCollum, "IS Guidance for Government Auditors," Internal Auditor, Vol. 59, No. 2, pp. 16-17, 2002.

5 John Silltow, "Shedding Light on Information Technology Risks," Internal Auditor, Vol. 60, No. 6, pp. 32-39, 2003.

${ }^{6}$ Ahmad Abu-Masa, "Auditing E-Business: New Challenges for External Auditors," Journal of American Academy of Business, Cambridge, Vol. 4, No. 1/2, pp. 28-41, 2004.

${ }^{7}$ James L. Bierstaker, Priscilla Burnaby, and Jay Thibodeau, "The Impact of Information Technology on the Audit Process: An Assessment of the State of the Art and Implications for the Future," Managerial Auditing Journal, Vol. 16, No. 3, pp. 159-164, 2001.

${ }^{8}$ George H. Tucker, "IT and the Audit," Journal of Accountancy, Vol. 192, No. 3, pp. 41-43, 2001.

${ }^{9}$ Sally Chan, "Sarbanes-Oxley: The IT Dimension," Internal Auditor, Vol. 61, No. 1, pp. 31-33, 2004.

10 "Public Company Accounting Oversight Board Bylaws and Rules - Standards, Auditing Standard No. 2," [Effective pursuant to SEC Release No. 34-49884; File No. PCAOB-2204-03, June 17, 2004].

${ }^{11}$ AICPA Professional Standards, New York: American Institute of Certified Public Accountants, Section AU319.

${ }^{12}$ Eric N. Johnson, Jane Baird, Paul Caster, William N. Dilla, Christine E. Earley, and Timothy J. Louwers, "Challenges to Audit Education for the 21st Century: A Survey of Curricula, Course Content, and Delivery Methods," Issues in Accounting Education, Vol. 18, No. 3, pp. 241-263, 2003.

${ }^{13}$ Eric N. Johnson, Jane Baird, Paul Caster, William N. Dilla, Christine E. Earley, and Timothy J. Louwers, "Challenges to Audit Education for the 21st Century: A Survey of Curricula, Course Content, and Delivery Methods," Issues in Accounting Education, Vol. 18, No. 3, pp. 241-263, 2003.

${ }^{14}$ Cynthia D. Heagy and Peter L. McMickle, "An Empirical Investigation of the Accounting Systems Course: Academic Practice Versus Practitioner Needs," Issues in Accounting Education, Vol. 3, Issue 1, p. 96, 1988.

${ }^{15}$ Bruce A. Baldwin and Dan C. Neer, "EDP Audit Education and EDP Auditor Characteristics: Empirical Data from Practitioners and Professors," Issues in Accounting Education, Vol. 1, Issue 1, p. 153, 1986.

${ }^{16}$ Alan T. Lord and Frederick Gallegos, "ISACA Model Curriculum 2004: Continuing to Invest in the Future," Information Systems and Control Journal, Vol. 6, 2004.

${ }^{17}$ Alan T. Lord and Frederick Gallegos, "ISACA Model Curriculum 2004: Continuing to Invest in the Future," Information Systems and Control Journal, Vol. 6, 2004.

${ }_{18}^{18}$ James R. Hasselback, Accounting Faculty Directory 2004-2005 (Upper Saddle River, N.J.: Prentice Hall, 2004).

${ }^{19}$ James R. Hasselback, Accounting Faculty Directory 2004-2005 (Upper Saddle River, N.J.: Prentice Hall, 2004).

${ }^{20}$ R.M. Diamond, Designing and Improving Courses and Curricula in Higher Education: A Systematic Approach (San Francisco: Jossey-Bass Inc., 1989). 


\section{NOTES}

